\title{
Field investigation of slab deterioration due to carbonation in a concrete building
}

\author{
Eleni B. Araya ${ }^{1, *}$, Stephen Ekolu ${ }^{1}$ and Fitsum Solomon ${ }^{1}$ \\ ${ }^{1}$ Department of Civil Engineering Science, University of Johannesburg, Auckland Park 2006, Johannesburg, South Africa
}

\begin{abstract}
This paper presents an investigation on a deteriorated slab of a two-story building located in Johannesburg, South Africa. The structure has been in use as a residential building for more than 60 years. The top slab of the first floor was delaminated and reinforcement bars were severely corroded. Condition assessment of the building was done using the Schmidt hammer test, covermeter survey and half-cell potential measurements. In addition to the non-destructive tests done, Xray diffraction and scanning electron microscopy were also conducted on the deteriorated concrete.
\end{abstract}

Key words: Carbonation, Cover, Corrosion, Non-destructive tests, Reinforced concrete, Spalling, Site inspection.

\section{Introduction}

Reinforced concrete is the most widely used construction material due to its great versatility. However, the steel reinforcement is thermodynamically unstable under normal atmospheric conditions and converts into its natural state which is iron oxide or rust. This phenomenon of steel conversion into rust or iron oxide is the corrosion process [1]. Carbonation and chloride attack are the two main causes of corrosion of steel in concrete. The interaction of carbon dioxide in the atmosphere with the alkaline hydroxides in the concrete causes a reduction in $\mathrm{pH}$ which can lead to carbonationinduced corrosion. When carbon dioxide dissolves in pore water it forms carbonic acid that neutralizes the alkalis and forms calcium carbonates. Gradually as this reaction continues, it reduces the $\mathrm{pH}$ of concrete from 12.5 to a level below 9.0 at which steel corrosion can take place with available sufficient air and moisture. Chloride ions can penetrate into concrete from sea water, salty groundwater or de-icing salts. Once they come into contact with the steel in concrete, chlorides facilitate the breakdown of the passive layer of oxide on the steel and lead to corrosion [2-6]. Corrosion in reinforced concrete structures results in the loss of steel cross-sectional area and loss of bond between steel and the surrounding concrete. Furthermore, the products of corrosion expand and induce tensile stresses in the surrounding concrete. This stresses lead to internal cracking, cover spalling and delamination [7-8].

Before commencing any repair strategy, an appropriate diagnosis of the deterioration process is necessary. Diagnosis of distress can be conducted using condition assessment methods that commonly involve non-destructive (NDT) field testing and laboratory analyses on core or dust samples [9-11]. One of the most widely used NDT corrosion assessment methods is the half-cell potential procedure standardized in ASTM C876 [12].

In this study, various in-situ tests and laboratory analyses were done including visual inspection, Schmidt hammer test, cover-meter survey and half-cell potential measurements. In addition, X-ray diffraction (XRD) and Scanning Electron Microscopy (SEM) were also conducted on the concrete samples taken from the deteriorated slab.

\section{Background}

An investigation was conducted to evaluate corrosion attack in a reinforced concrete building that had been in service for more than 60 years in Johannesburg, South Africa. This was done by conducting condition assessment. From the visual inspection conducted, it was observed that there was extensive spalling of concrete cover and severe corrosion of exposed reinforcement at the soffit of the roof slab shown in Fig. 1. To extend the service life of the building, repair and maintenance of the structure would be required. Therefore, conducting a detailed investigation was necessary to evaluate the condition of the building for continuation of its service to the residents.

Johannesburg is an inland city with tropical climate conditions. As such, no chloride exposure conditions arise. However, it is a major urban city with substantial industrial pollution responsible for carbonation as the main mechanism of steel corrosion, as already established in past studies [4-5, 9-10]. 


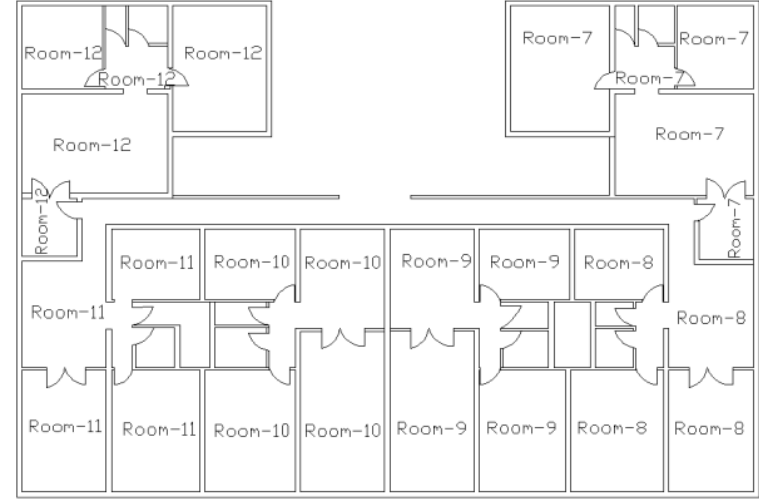

Fig. 1. First floor plan of the reinforced concrete building labeled from Room-7 to Room-12.

During this study, the structure was in use as a community residential building. Accordingly, the regime of tests were restricted to only non-destructive measurements. The main objectives of this research were:

- To assess and identify the type and mechanism of corrosion occurring at the two-story reinforced concrete building by conducting condition assessment.

- To investigate the corrosion attack by conducting an analytical study of the deteriorated concrete.

\section{Condition assessment of the building}

\subsection{Field measurements}

\subsubsection{Visual inspection}

Visual inspection is typically the first step in condition assessment. Hence, the assessment commences visual inspection with photographic recording and documenting the visible deteriorations such as spalling, loss of concrete cover and corroded reinforcement bars. Fig. 2 gives a distressed area showing total loss of the concrete cover and severe corrosion of bars at the soffit of the roof slab.

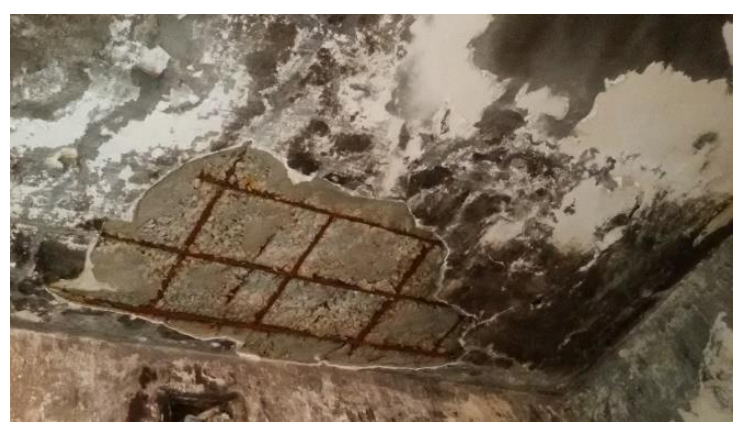

Fig. 2. Exposed rebars and delamination at Room-9 of Fig. 1.

\subsubsection{Schmidt hammer test}

The Schmidt hammer test was done to determine the insitu compressive strength of the concrete. The strength measurements were conducted on all 26 rooms (from Room-7 to Room-12) in $1 \mathrm{~m} \times 1 \mathrm{~m}$ grid space of the slab in Fig. 1. Altogether 1294 data points of rebound values were collected. Using the manufacturer's data, the rebound values have been converted into corresponding compressive strengths. Fig. 3 shows the Schmidt hammer test in progress.

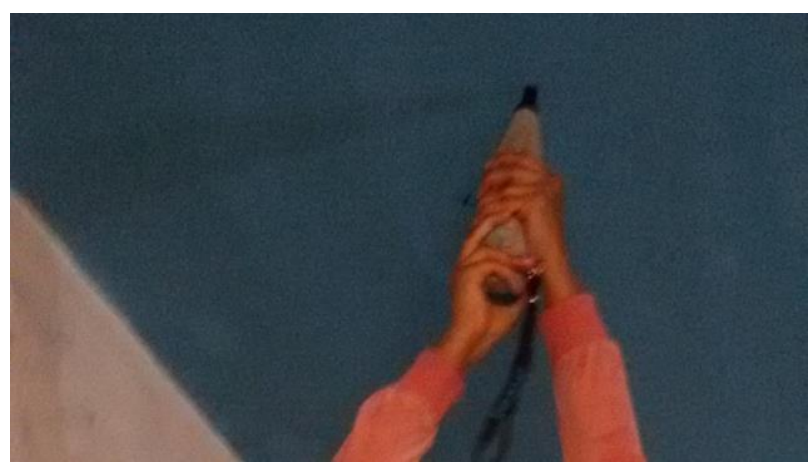

Fig. 3. Schmidt hammer measurement at the soffit of the roof slab.

The indicative concrete strength data obtained have been plotted in a histogram shown in Fig. 4. The mean compressive strength was found to be $17.1 \mathrm{Mpa}$ with a standard deviation of 4.9 .

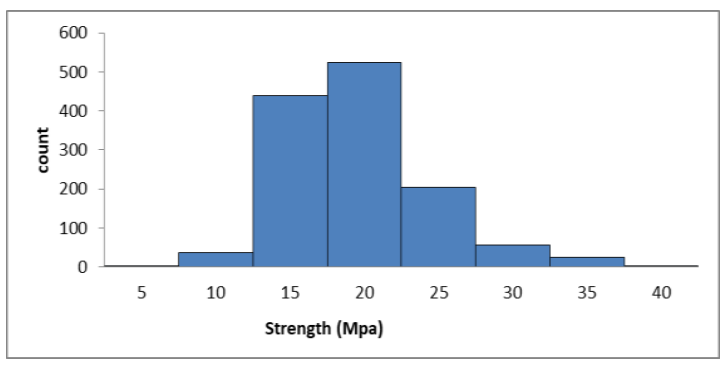

Fig. 4. Histogram of Schmidt hammer test data.

\subsubsection{Cover-meter survey}

A cover-meter survey was conducted to determine the concrete cover depth and to check bar location. The same grid of $1 \mathrm{~m} \times 1 \mathrm{~m}$ as mentioned in Section 3.1.2 was used for the cover-meter survey as well. Fig. 5 shows the actual cover meter measurements being conducted. Fig. 6 gives a plot of the concrete cover results in a histogram. The 2580 data measurements collected, gave a mean concrete cover of $19.5 \mathrm{~mm}$ with a standard deviation of 5.2.

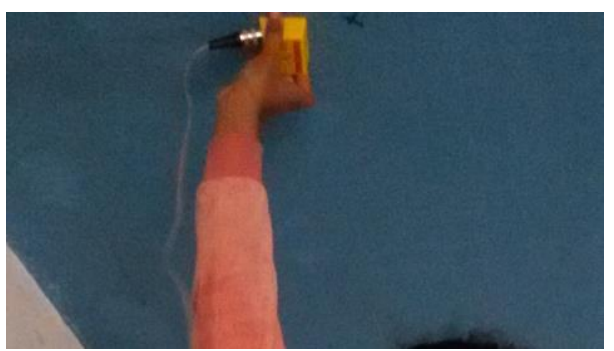

Fig. 5. Cover-meter measurement at the soffit of the roof slab. 


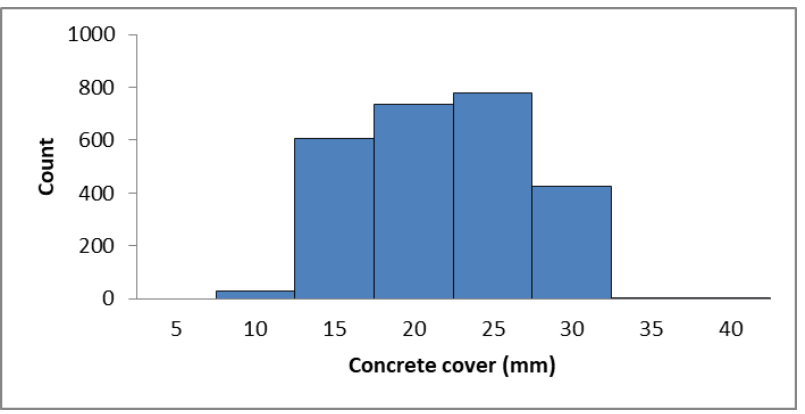

Fig. 6. Histogram of the cover-meter results.

\subsubsection{Half-cell potential measurement}

The half-cell potential method was used to asses the corrosion level of steel reinforcement. A total of 155 data sets were collected. Fig. 7 shows the half-cell potential measurement in progress. The measurements were taken at random spots across the slab soffit. Also given in Table 1 are data showing the minimum and maximum values obtained at the various locations. It can be seen that the readings ranged from $+85 \mathrm{mV}$ to -687 $\mathrm{mV}$. All the data obtained has also been plotted in a histogram shown in Fig. 8. The mean half-cell potential reading was $-202.9 \mathrm{mV}$ with a standard deviation of 138.0. Most highly negative half-cell potential readings were recorded at points where there was roof leakage and delamination. These highly negative readings were likely due to oxygen starvation.

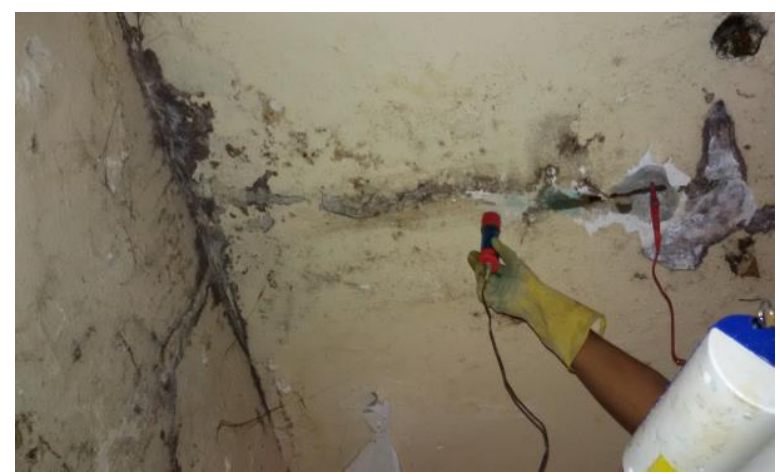

Fig. 7. Ongoing half-cell potential measurement at the soffit of the roof slab.

Table 1. Maximum and minimum values of the half-cell potential readings.

\begin{tabular}{|l|c|c|c|}
\hline \multirow{2}{*}{ Flat } & \multicolumn{2}{|c|}{$\begin{array}{c}\text { Half-cell potential reading } \\
(\mathrm{mV})\end{array}$} & $\begin{array}{c}\text { Number of } \\
\text { data } \\
\text { collected }\end{array}$ \\
\cline { 2 - 4 } & Maximum & Minimum & \\
\hline Room-7 & 85 & -247 & 58 \\
\hline Room-8 & -246 & -481 & 18 \\
\hline Room-9 & -15 & -687 & 29 \\
\hline Room-11 & -114 & -420 & 50 \\
\hline Total & \multicolumn{3}{|c|}{} \\
\hline
\end{tabular}

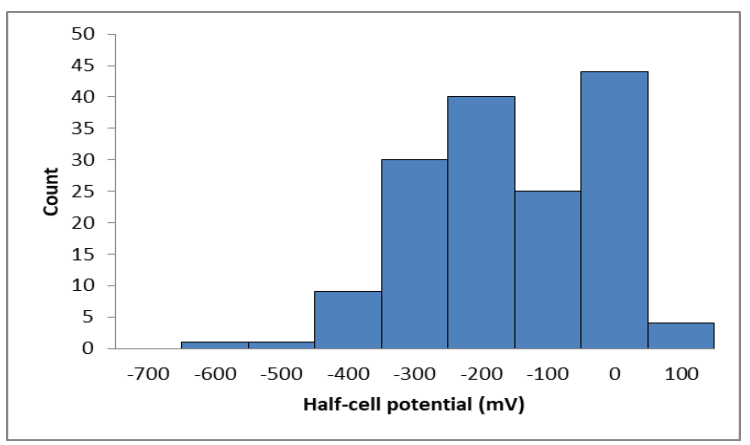

Fig. 8. Histogram of the half-cell potential measurement data.

\subsection{Analytical study}

After the field condition assessment was done, an analytical study was conducted on concrete samples collected from the RC building.

\subsubsection{X-ray diffraction}

XRD analysis was conducted at $40 \mathrm{KeV}, 15 \mathrm{~mA}$ using a Rigaku MiniFlex 600 Benchtop diffractometer with $\mathrm{Cu}$ $\mathrm{K} \alpha$ radiation $\left(\lambda=1.5418 \AA\right.$ ) over $2 \theta$ angle of $0^{\circ}-90^{\circ}$ at room temperature. Fig. 9 shows the presence of calcium carbonate, which may be attributed to carbonation as per Equation (1).

$$
\mathrm{Ca}(\mathrm{OH})_{2}+\mathrm{CO}_{2} \longrightarrow \mathrm{CaCO}_{3}+\mathrm{H}_{2} \mathrm{O}
$$

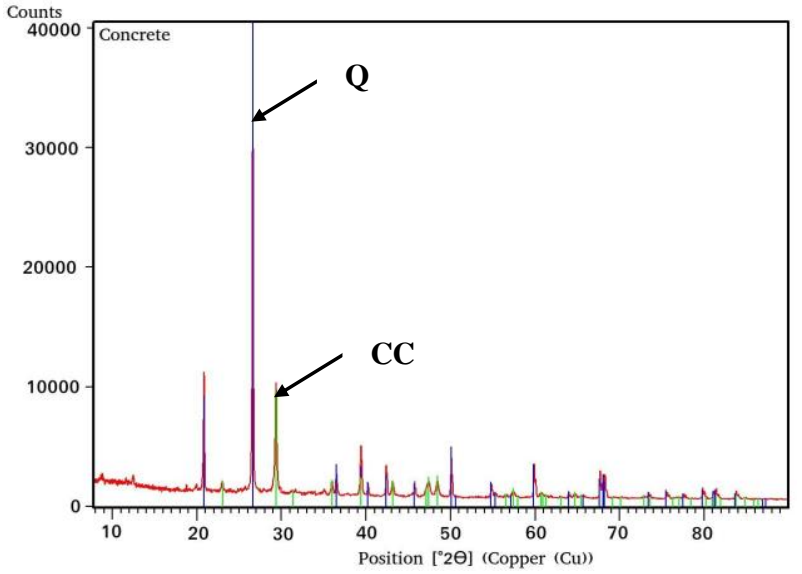

Fig. 9. XRD pattern of the concrete sample, showing calcium carbonate (CC) and quartz (Q).

\subsubsection{Scanning Electron Microscopy}

SEM coupled with Energy Dispersive Spectroscopy (EDS) were used to examine the morphology (see Fig. 10) and the presence of metal ions (see Fig. 11) in the concrete sample, respectively. The presence of calcium $(\mathrm{Ca})$, silicon $(\mathrm{Si})$, carbon $(\mathrm{C})$, and oxygen $\left(\mathrm{O}_{2}\right)$ in the concrete sample was identified using EDS analysis (see Fig. 11) which supported the XRD results. 


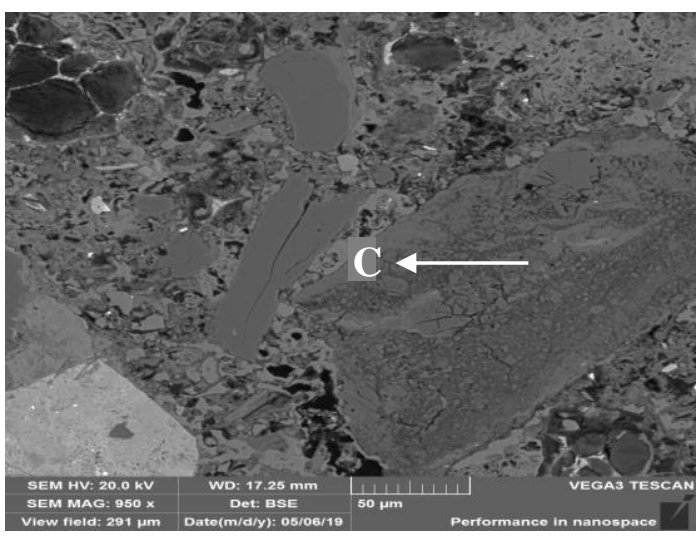

Fig. 10. SEM image of the concrete sample. Symbol C indicates the location where the EDS analysis was performed.

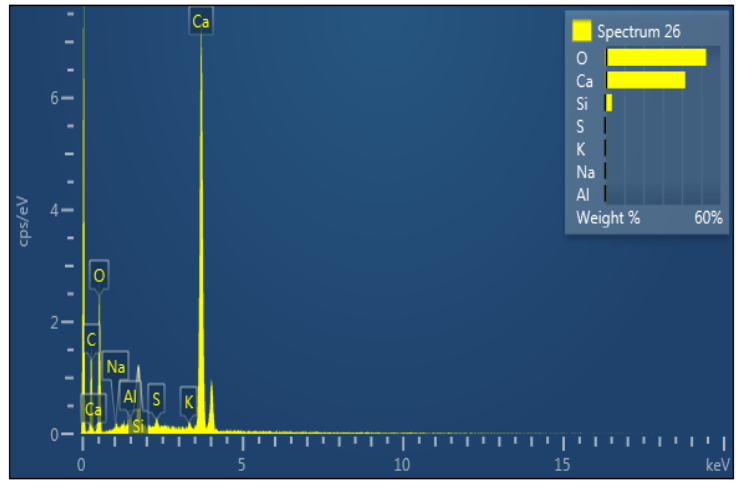

Fig. 11. The result of EDS analysis taken at the point marked with symbol $\mathrm{C}$ in Fig. 11.

\section{Conclusion}

Field investigation involving condition assessment was conducted to evaluate deterioration of a community residential structure. In addition, an analytical study of the concrete samples taken from site was done which indicated carbonation attack to be the mechanism responsible for the observed corrosion of steel reinforcement in the reinforced concrete building. Concrete in the soffit of the roof slab was delaminated and steel reinforcement was severely corroded due to carbonation-induced corrosion. Further research is ongoing to determine appropriate repairs that may be employed.

\section{Acknowledgement}

The paper is based on the BERTRAMS Community Upliftment Project conducted under the NRF community engagement fund through the collaboration of Tshwane University of Technology (TUT) Architecture Department, CARINBE and Civil Engineering Science Department of the University of Johannesburg (UJ). The author would also like to acknowledge and thank the Global Excellence Stature (GES) of UJ, for the scholarship funding of Eleni Araya's masters study program.

\section{References}

1. PCA., Types and causes of concrete deterioration, Portland Cement Association (PCA): Skokie, IL, USA (2002)

2. J.P. Broomfield, Corrosion of steel in concrete: understanding, investigation and repair, CRC Press, 17-21 (2003)

3. S.O. Ekolu, M.D.A. Thomas and R.D. Hooton, Pessimum effect of externally applied chlorides on expansion due to DEF - proposed mechanism, Cement and Concrete Research, 36, 688-696 (2006)

4. S.O. Ekolu, A review on effects of curing, sheltering, and $\mathrm{CO}_{2}$ concentration upon natural carbonation of concrete, Construction and Building Materials, 127, 306-320 (2016)

5. S.O. Ekolu, Model for practical prediction of natural carbonation in reinforced concrete: Part 1formulation, Cement and Concrete Composites, 86, 40-56 (2018)

6. S.O. Ekolu and M. Allan, Treatment of a stochastic service life prediction model to an evaluation of a distressed two-story $R C$ building, Proc. 3rd Intl. Conf. on Concrete Repair, Rehabilitation and Retrofitting (ICCRRR), Cape Town, South Africa, 451-457 (2012)

7. S. Guzmán and J.C. Gálvez, Modelling of concrete cover cracking due to non-uniform corrosion of reinforcing steel, Construction and Building Materials, 155, 1063-1071 (2017)

8. V. Talakokula, S. Bhalla, R.J Ball, C.R. Bowen, G.L. Pesce, R. Kurchania, B. Bhattacharjee, A. Gupta and K. Paine, Diagnosis of carbonation induced corrosion initiation and progression in reinforced concrete structures using piezoimpedance transducers. Sensors and Actuators A: Physical, 242, 79-91 (2016)

9. W.F van Ede and S.O. Ekolu, Condition assessment of a Johannesburg skyscraper, Proceedings of the International Conference on Construction Materials and Structures (ICCMATS), Johannesburg, South Africa, 1052-1059 (2014)

10. S.O. Ekolu, Model verification, refinement and testing on independent 10-year carbonation field data, Proc. 3rd Intl. Conf. on Concrete Repair, Rehabilitation and Retrofitting (ICCRRR), Cape Town, South Africa, 445-450 (2012)

11. P. Gu \& J. Beaudoin, Obtaining effective half-Cell potential measurements in reinforced concrete structures, Corros. Sci., 97 (1998)

12. ASTM International C876-15, Standard test method for corrosion potentials of uncoated reinforcing steel in concrete, West Conshohocken, PA, (2015) 